\section{从空间视角看共享经济时代的城市 CITIES IN THE ERA OF SHARING ECONOMY: FROM A PERSPECTIVE OF URBAN SPACE}

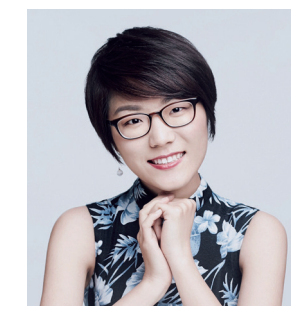

陈立群

中国城市和小城镇改革发展

中心城市规划师

\section{Liqun CHEN}

Urban Planner at

China Center for Urban

Development \begin{tabular}{l|l} 
DO1:10.15302/J-LAF-20170305 & $\begin{array}{l}\text { 收稿U寸间 RECEIVED DATE / 2017-06-05 } \\
\text { 中图分类号 / TU982 } \\
\text { 文献标识码/C }\end{array}$
\end{tabular}

摘要

城市是现代生活最重要的 “容器” , 其中不仅包括商品和信 息的交换, 还包括社会关系的生产和消费。也正是城市对商品、信 息、人、关系的集聚，催生了共享经济的繁荣和增长。从Airbnb、 Uber, 到共享单车、共享办公空间, “共享”似乎成为了一种新的 经济模型和范式, 随移动互联网向每个人的日常生活席卷而来。面对 以共享经济为代表的新经济模式和更加开放的社会关系, 城市生活不 可避免地发生了巨大变化。而当我们用“共享” 的视角看待城市, 将 共享经济的理念应用到城市中, 这不仅意味着城市内部动力和社会经 济过程将迎来变化, 也意味着城市空间将重新构建。为了应对这些变 化和挑战, 已经有多个城市开始了对更加共享、开放的城市图景的探 索, 而我们当前的城市空间框架似乎并未完全做好准备。本文从空间 性的视角出发, 将共享经济及其特征对应到城市空间的探讨中, 剖析 和展望这场共享革命中的城市空间。

\section{关键词}

共享经济；城市；公共空间；空间性

\section{ABSTRACT}

The city, where modern urban life happens, not only allows for the exchange of goods and information, but also accommodates the production and consumption of social relations. The gathering of goods, information, people, and social relations in cities has promoted the growth of sharing economy. From Airbnb, Uber, to shared bicycles and shared office space, the idea of "sharing" seems to have become a new economic model and paradigm which, along with the mobile Internet, is rolling into everyone's daily life. In facing the new economy, which is characterized by sharing economy, and the more open social relations, urban life is inevitably undergoing dramatic changes. When we examine the city through the lens of sharing and apply the concept of sharing into urban design and management, it will not only bring great changes to the city's internal dynamics and socio-economic process, but also lead to a reconstruction of urban space. Responding to these changes and challenges, a number of cities are seeking for a more shared and open future, yet which could not be supported by the current urban space. This article tries to discuss the sharing economy and its characteristics with the study of contemporary urban space in order to envision the future of urban space within this revolution of sharing.

KEY WORDS

Sharing Economy; City; Public Space; Spatiality

译 田乐 张健 


\section{1 从共享经济谈起}

共享经济最初起源于开源社区中用户之 间的产品与服务共享 ${ }^{[1]}$, 其爆炸式增长得益 于互联网时代大大降低的信息流动成本。扁 平化的市场空间、透明的交易过程和完备的 信用体系使得资源流动的成本和风险大大降 低, 因此产品与服务能够被更频繁、更高效 地交换和共享。

随着互联网经济的蓬勃发展, 共享经 济的外延不断拓展, 出现了诸如 “协同消 费” “协作经济” “P2P经济” 等相关概 念。在缺乏统一定义的前提下, 我们暂且简 单地将共享经济理解为: 拥有闲置资源 (或 人力）的机构或个人，将资源的使用权临时 转渡给他人, 以创造更多价值。这种 “共同 使用而不占有” 的模式与传统经济模式具有 显著差异。

\section{1 闲置资源的优化利用}

对于资源的拥有者来说，闲置资源的社 会化利用能够以很低的成本带来额外收益。 而对于资源的使用者来说，“租用”资源获 得临时使用权的成本远低于永久性购置。这 种资源拥有者与使用者之间的交换，使原本 被有限使用的物品得到了更充分的利用。

\section{2 使用权的切分和转让}

在共享经济中, 人们关心物品的使用价 值, 而非占有。所有权和使用权的分离, 使 物品能够在不改变所有权的情况下, 进行社 会化利用。对于房屋、车辆等具有使用排他 性的资源来说，在不同使用者之间的转换， 意味着使用权被分割成不同的区段; 对于数
据、信息服务等具有非排他性的资源来说, 使用权由有资格的使用者共同享有。

\section{3 去中心化的组织结构}

在互联网技术的支持下，共享经济将分 散的使用者和供给者整合于一个共同的集体 利益网络, 体现了一种更为自发的秩序和合 作。在理想的共享经济状态中, 个体同时作 为资源和服务的供给者和使用者，从而大大 降低了对集中组织管理的需求。可以预见的 是, 随着互联网开源框架和区块链等新技术 的完善, 由共享经济带来的商品交换的去中 心化程度会不断提高。

总体来看, 共享经济构建了一种开放的 价值交换体系, 让不同角色以积极参与者的 身份加人到扁平化的社会经济共同体中, 从 而提升系统的活力和资源的使用效率。

\section{2 城市空间与普通物品有何差异?}

共享经济中的 “共享”，似乎意味着更 加开放和互动的社会经济过程和生活方式。 这些理念是否可以应用到城市空间中? 在回 答这个问题之前, 需要明确的是: 城市空间 与可交换的物品之间存在诸多差异, 不仅体 现在城市的系统性和复杂性中, 还体现在 “空间” 这一概念的特殊性之中。

\section{1 空间性}

城市中的一切活动一一通勤、交易、生 产、生活, 即亨利 - 列斐伏尔所说的 “空间 实践” , 都发生在城市空间中。城市空间, 尤其是公共空间, 是城市实现功能运转和资 源共享的场所和粘合剂。 
相对于可以交换的普通商品, 空间不 是一种纯粹的外在物质存在, 而是一个社会 过程。这一特征使我们很难将空间及其中发 生的事件和进程分割开来。这种过程性意味 着 “在场” 在空间体验中永远是必要且重要 的。虽然信息和通信技术已经让多种生产要 素实现了在区域乃至全球尺度的配置, 生产 不再需要所有生产要素出现在同一空间, 远程办公、远程通信在技术上也已经实 现, 但面对面交流仍然是必要且关键的。且 由于对具有单一生产功能空间的区位要求的 降低, 具有社会交往、休闲、创新、共享特 征的城市空间, 尤其是公共空间将变得越来 越重要。

第二次世界大战之后, 发达国家在社会 基本摆脱物质匮乏阶段之后, 逐渐实现由生 产型的工业社会向消费型的后工业社会的转 型。社会从在空间中的生产转向对空间本身 的生产 ${ }^{[2]}$; 相应地, 在空间中的消费也成为 对空间过程本身的消费, 空间本身成为一种 产品。

\section{2 权责的复杂性}

对于一般的商品交换和共享过程来说, 物权关系相对简单, 使用权能够被交换和转 让，而城市空间却很难界定其所有权和使用 权。空间的权责不仅仅包括使用, 还包括管 理、经营、占用, 因此 “共享” 所涉及的空 间问题不仅仅是简单的使用和可及, 还包括 诸多具有一定排他性和独占性的权责。

虽然拥有较为明确产权/使用权的私有 化空间和准私有化空间可以通过设置准人条 件将空间的使用权分时、分用途转让, 但空 间本身的不可移动性和可叠加服务的丰富性
都使得空间共享与物品共享区分开来。以共 享办公空间为例, 使用权被私有化的办公空 间在本质上与车辆等市场化产品一样, 是一 种具有清哳产权和使用权的资源, 这种功能 性的私有化空间可以将使用权分时切分, 甚 至结合多种增值服务, 使其作为商品进行转 让。但办公空间可以同时容纳多个使用者, 其所提供服务的边际成本会随着使用者的增 多而降低, 这种非排他性特征为更为复杂的 准人规则和多样的共享模式提供了可能。更 加值得注意的是, 共享空间能够将活跃的使 用者组成联系紧密的社群, 进而实现更多维 度的交流共享。

对于公共空间来说, 其使用者在名义上 是城市中的每一个人, 这也往往意味着没有 人能够宣称拥有公共空间。这一非排他特征 “预设了对空间的拥有和集体管理会被利益 相关的各方不断干预, 从而形成多重利益关 系” [3]。在操作层面, 公共空间涉及的可让 渡权责包括管辖权、管理权、建设权、使用 权等。这些权责在不同群体的分布, 构成了 城市公共空间复杂的主体关系网络:

1 ）所有权: 全民所有/国有。由于一些 特殊政策, 包括纽约在内的少数城市也存在 私人拥有的公共空间。

2 ) 建设和开发权: 政府或开发商。

3 ) 管理权: 地方和城市政府, 其拥有被 国家赋予的管理权, 即对城市空间的实际管 辖权。这种管辖权在实际操作层面又被划分 至不同部门。

4 ) 使用权: 名义上的每一个人。与主 动的实践权/管理权相比, 使用权更为被动。 管理者能够通过设置使用门槛（往往是隐性 的）将一些潜在的公共空间使用者排除在外。

\section{3 公共空间的社会价值}

在经济学中, 公共空间具有公共产品或 准公共产品特征。高质量的公共空间不仅能 为使用者带来裨益, 还能够提高周边地区和 整个城市的价值。然而, 公共空间并不能产 生直接的经济回报。换句话说，公共空间生 产的是社会价值, 其回报和效用很难被量化 或货币化。这一特征决定了城市空间作为一 种资源，其社会价值的最大化必须要有政府 (作为公共利益的管理者) 的介人, 这种介 人的途径可能是监管、有条件转让或直接运 营管理。

\section{3 “共享” 能够为城市带来哪些改变?}

由于城市的空间性、权责的复杂性、产 生价值的社会性等特征, “共享” 这一概念 赋子了城市空间更加丰富的内涵。作为城市 过程的媒介和催化剂, 城市空间优化利用、 使用权切分让渡、去中心化组织的实现，不 仅会改变使用者的空间体验, 还将在更深层 面上影响城市社会的运转机制。

\section{1 资源优化利用, 发挥空间价值}

城市空间是一种资源，城市的公共空间 更是属于城市共同体的稀有资源，它可以创 造出巨大的社会价值, 也具有被优化利用的 可能。

在共享经济中, 由于信息工具和使用 权让渡机制的存在, 大量原本只能被产权相 关者 (往往是拥有者) 使用的资源进人到扁 平化的大众市场, 使得原本没有资格使用这 些资源的人获得了利用其创造新价值的可 能。对于这些资源来说, 其被使用的频率和 
时长都得到了增加；对于普通的市场参与者 而言, 其可以临时占有原本属于其他人的物 品或资源, 可选择的资源数量和类型大大增 加; 对于城市空间来说, 空间可达性的提升 和分时利用能让原本只具有单一固定功能的 空间在不同时段、不同环境下被不同的使用 人群利用, 这正是城市时空多样性和24小时 持续活力的来源。

\section{2 去中心化的组织结构一一共同参与}

城市空间的共享，应该是根植于实践过 程和参与角色的多元。共享理念下的城市空 间不仅仅意味着使用的开放, 还意味着需要 重新思考空间生产的机制，将多种角色、多 方力量引人到空间塑造的过程中。

移动互联网已经大大提升了人们获取、 解读和利用信息的能力, 通过各类社交媒 体、传感器及新型信息工具, 人的行为和观 点能够被数字化, 并进行即时交互。一旦个 体与空间的互动被信息化, 并通过互联网扁 平化的结构进行传播和叠加, 在场与不在场 的相关个体便都有机会与空间进行互动, 为 空间塑造贡献力量。

\section{3 权责的转换一一城市共享的核心}

共享经济的核心是使用权的切分和转 让，而对于城市空间，我们关注的是：通过 划分和转换何种权责, 能够实现空间的更高 效利用及创造更高的社会价值?

1 ）空间的使用权：打破占有，降低不同 形式的空间使用门槛。

2) 空间的建设权和管理权: 公共部门的 赋权，以及引入空间建设和管理的多方参与 机制。一方面，通过公私合营等模式，让有
能力的私营企业或机构有机会参与到城市基 础设施和公共空间的建设和管理中，提高公 共服务的供给效率和灵活性; 另一方面，引 人公众参与机制，增加市民参与空间营造 的途径, 改变城市空间管理过程与使用过 程分离的现状，让使用者同时成为管理者 和实践者。

3 ) 共同拥有与社群: 空间营造和参与通 过让使用者和社区成员承担治理的责任和思 考, 使他们从原本的使用者变为参与主体。 正如共享经济能够通过网络平台建立具有 共同兴趣的网络社群，基于空间的组织和 合作平台也能形成如社区治理组织、社区基 金会等自发组织，成为影响城市空间的强大 力量。

正如邓肯・麦克拉伦和朱利安・阿杰 曼在《共享城市》一书中所倡导的：“共 享的范式”可以包含多个维度, 从共享物 品、共享服务, 到共享活动和体验, 也包 括个体与公共资源之间的共享。当城市形 成一种打破占有、垄断的, 更加开放的空 间过程, “大量市民的创造性力量能够突 破传统层级式管理和商业组织, 通过电子 平台等工具被协调起来”，成为 “协同共 享”或 “共同对等生产”。

\section{4 当前城市空间面临哪些共享问题?}

城市空间是一个巨大的连续体，不论 是在整体还是局部层面, 都比一般物品的共 享面临更多的困难和问题。空间作为一个有 机整体，在城市的管理中缺乏整合的管理主 体，空间过程被划分到诸如园林、交通、城 市管理等不同的政府部门。空间本应具备的 
统一过程和破碎的管理权造成了政府对空间 事件和过程的管理真空和高品质空间的供给 缺失。

这种高品质 “空间产品” 的匮乏, 将原 本应该由城市提供的公共服务让渡给了能够 满足这一需求的市场力量, 为私有化的 “伪 公共空间” ${ }^{[5]}$ 创造了巨大的生存空间。于是 公共性的商业街道被购物中心取代, 城市住 宅被封闭小区取代, 城市公园被主题公园取 代; 看似公共但其实只是供少量人群使用的 绿地、庭院、小广场不断增加。不管开放性 如何, 这些空间已经不再是传统意义上的公 共空间, 其所有者或管理者有权根据自身的 需要, 为空间的使用者制定一整套安全措施 和管理条例。这样一来, 这些非公共所有的 空间的可达性和真实性都大大降低 ${ }^{[6]}$ 。

私有化公共空间的理念在几次世界及区 域性的经济危机后, 在世界各地的城市中得 到了广泛应用 ${ }^{[7]}$ 。以纽约为例, 根据纽约非 营利组织 “倡导私有化公共空间” 的统计, 自1961年《区划法》中增加了激励性措施 后, 出现了超过500个私有公共空间 ${ }^{\mathbb{1}}$ 。根据 英国《卫报》的调查, 伦敦的私有化城市空 间出现于 20 世纪 80 年代, 其数量在 2000 年以 后呈现稳定增长 ${ }^{2}$ 。

这种现象顺应了后现代城市广泛的治理 和管理私有化进程, 而推动该进程的根本动 力是新自由主义框架下的政治经济结构的转 型和政府职能的战略性撤退：政府缩小公共 管理范围, 减少对公共空间的投人, 将相当 部分的公共资源转移给私人资本运营。这一 现象并非公权力的膨胀, 恰恰相反, 是公权 力在城市空间中的缺位。在这一背景下, 开 放和共享的城市空间图景就变得尤其珍贵。

\section{5 方向：共享革命中的探索}

以上所描述的更加开放的城市空间营造 过程并非凭空想象, 而是来自于当前城市社 会应对所面临的共同挑战的解决方案, 以及 新技术和市民觉醒所带来的新机会。

在共享经济得到快速发展的旧金山，市 长办公室的公民创新工作组发起了名为 “生 活创新区” ( LIZ) 的项目, 在城市中心的 街道开辟出一片特殊的区域, 鼓励并支持市 民、艺术家和城市工作者去实现他们的空间 营造想法。从2013年开始, LIZ已先后建造了 6 个通过开放征集得到的街道营造项目, 成为 了真正的空间营造试验场 ${ }^{3}$ 。在纽约, 名为 “公园无界” 的城市公园促进项目自2015年 开始实施, 这个总预算超过5 000 万美元的项 目聚焦于纽约公园的角落、边界和其他没有 得到充分利用的空间, 通过拆除公园围栏、 景观改造等方式, 提高公共空间的开放性和 吸引力 ${ }^{\oplus}$ 。

首尔自2012年开始共享城市建设, 由市 政府实施了车辆共享、图书共享、公共资源 开放、住房共享等多项举措。其中自2012年 开始实施的公共设施开放服务, 将公共建筑 等资源于非工作时间向公众开放，截至2016 年, 共有超过 1200 处公共建筑空间被超过 31 万人次所使用 ${ }^{5}$ 。

在深圳, 68位街头艺人于 2015 年获得了 首批街头艺人证, 标志着公共艺术事件被纳 人了城市管理的范畴 ${ }^{\circledR}$ 。在上海, 2015 年开 始推出的城市空间艺术季平台将城市的管理 者、使用者、策展人、艺术家乃至企业聚集 到一起, 共同发现和改变城市公共空间 ${ }^{\text {? }}$ 。在 北京, 以“大栅栏更新计划” 和 “白塔寺再
生计划” (9)为代表的城市微更新实践也成为了 城市空间经营的先行者。

在这场从垄断到开放、从占有到共有、 从社区到社群的革命中, 这些城市的创造和 尝试形成了宝贵的经验, 为我们呈现了未来 城市的一些空间轮廓。这些实践也凸显出当 前城市管理和公共空间营造所面临的关键性 问题, 对这些问题的探索和挖掘将为城市空 间的经营带来进一步的启发:

1 ）空间管理的破碎化: 城市对公共空间 的管理依据资源类型划分到不同部门中, 导 致管理的重点被放在实体资源而非空间过程 上, 造成空间管理主体缺失或重叠。

2 ) 空间参与激励机制：高品质公共空 间对城市和场地的积极影响是长期的、难以 被量化的。可以预见的是, 如果这种外部 性能够转化为城市管理和多方参与的驱动 力, 城市和个体对空间营造的投人将得到显 著的增加。

3 ) 空间信用体系的缺失：完善的信用 体系是共享经济的必要支撑, 它通过支付、 评价、沟通等一系列过程来建立有序的共 享秩序, 提升系统的整体安全性。在城市 空间营造的过程中, 如何建立不同角色之 间的信任和合作机制，将新的空间参与者引 人到原有的权责秩序中, 是当前尚未解决的

问题。LAF

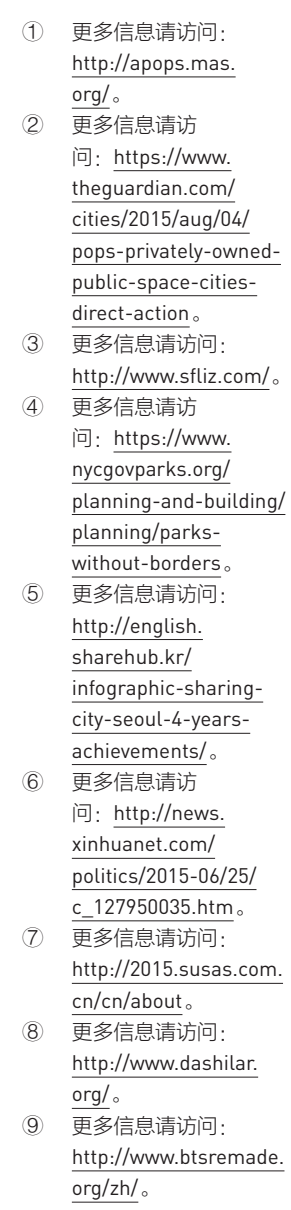




\section{Sharing Economy}

Sharing economy is originated from the sharing of products and services in the open-source community ${ }^{[1]}$. Its exponential growth benefits from the great reduction of the cost of information flows in the Internet times. Flattening market, transparent trading process, and a well-established credit system together make the cost and risk of resource flow greatly reduced, thus products and services can be more frequently and more efficiently exchanged and shared.

With the rapid development of the Internet economy, the concept of shared economy has been largely extended into collaborative consumption, collaborative economy, and peer-to-peer economy, etc. So far there is not a universal definition of sharing economy, which, in this paper, is perceived as an institution or an individual with underused resources (or human resources) that can be temporarily used by the others to create more values or bring more benefits. The property of this joint-use non-possession model is significantly different from the traditional economic models.

\subsection{Optimized Use of Resources}

For the resource owners, the jointuse of idle resources can bring additional benefits with little cost. For the resource users, "renting" resources to obtain temporary right of use costs much lower than purchase. Once unutilized items can be best utilized through the resource joint-uses.

\subsection{Division and Transfer of the Right to} Use

In sharing economy, people care about the right to use, rather than possession. The separation of ownership and right of use of a good supports social sharing. The user switch of exclusive resources, such as real estates and vehicles, means that the right to use is being divided; for the non-exclusive resources, such as data and information services, the right to use is shared by all the qualified users.

\subsection{Decentralized Organization Structure}

With the support of internet technologies, sharing economy integrates decentralized users and suppliers into a collective network with shared interests, forming a more spontaneous order and cooperation. Ideally, sharing economy allows the individuals to perform as resource or service providers and users at the same time that will greatly reduce the demand for centralized organization and management. It is foreseeable that, with the support of new technologies including open source framework of Internet and block chain, the good exchange led by sharing economy will be further decentralized.

In general, sharing economy builds an open exchange system that allows 
resource owners and users to join into the flattening socio-economic commune, in order to enhance the vitality of the system and the efficiency of resource use.

\section{What Is the Difference between Urban Space and Ordinary Goods?}

The "sharing" part in sharing economy seems to lead to more open and interactive socio-economic processes and lifestyles. Understanding this, we want to ask: can these ideas be applied to urban space? Before answering this question, we need to make clear that there are many differences between urban space and the exchangeable items, which is due to not only the systematic and complex nature of the city, but also the particularity of the concept of "space."

\subsection{Spatiality}

All urban activities, including commute, trade, production, and living, what are the "spatial practices" introduced by Henri Lefebvre, occur in cities. Urban space, especially the public space, is the exact place and medium that ensures the functional operation and resource sharing of a city.

Compared to the ordinary goods which are exchangeable, space cannot be considered as a purely external physical existence. Space is a social process. Its attribute of spatiality makes it scarcely possible to separate the activities and processes from the space itself, which means that "presence" is always necessary and essential to experiencing a space. Now that information and communication technologies have enabled to gather regionally or even globally distributed production factors to make a production. In other words, making a production no longer requires for all production factors being in the same place, which can be supported by the telecommuting and remote communication technologies. However, face-to-face communication is still absolutely necessary. Along with the spaces of single production function are not necessary to occupy valuable city land resources, urban space, especially public space, which can provide social, recreational, innovative, and sharing services, will become increasingly important.

The history of developed countries after the Second World War shows that when the basic material needs are met, the society would progressively turn to consumption-oriented post industry from production-oriented industry, turn "production in space" to "production of space," [2] and turn "consumption in space" to "consumption of spatial process" - the space itself becomes a product as well.

\subsection{Right and Responsibility}

In the process of exchange and sharing of ordinary goods, the 
simple and clear property rights and responsibilities can be explicitly exchanged and transferred. However, the ownership and the right to use of urban space are difficult to be defined. The right and responsibility of space involves the right to use, management, operation, occupation, and other aspects, thus space sharing does not simply concern about use and accessibility; it is also about rights and responsibilities related to exclusivity.

The explicit ownership / right to use of private space or quasi-private space can be transferred by time or by function through certain access requirements. But the immovability of space and the service multiplicity make spatial sharing complex. For example, an office space of privatized right to use is, in essence, a resource with clear property rights. Like vehicles or other commercial products, the right to use of the office space can be transferred by time or combined with value-added services, to generate more economic benefits or get traded. However, office space can accommodate multiple users at the same time, and the marginal cost would be reduced with the increase of users. This non-exclusive use complicates the access requirements and provides diverse sharing modes. Noteworthily, shared space can unite the users and form a close community that facilitates exchange and sharing in more dimensions.

Technically, the user of public space can be anyone in the city. This nonexclusive right to use "presupposes that the collective ownership and public authority of a certain space is intervened by the stakeholders to have multiple interests. ${ }^{[3]}$ " The transferable rights and responsibilities of a certain public space cover jurisdiction, management, construction, occupancy, etc. These rights and responsibilities involve different social communities and classes that constitutes a complex network of urban public space:

1) Ownership: owned by all people / state-owned. Privately-owned public spaces are legally allowed in the cities such as New York due to certain policies.

2) Right to construct and develop: by governments or developers.

3) Management right: by local and municipal governments. The governments have the administrative right over urban spaces, which is granted into different government agencies in implementation.

4) Right to use: by every citizen, technically. Compared to the management right owner (local and municipal government), the user is passive. Administrators can exclude certain potential users by setting access requirements (which are often implicit).

\subsection{The Social Value of Public Space}

In economics, public space has the quality as being public goods or quasipublic goods. High quality public space 
not only benefits the users, but also helps improve the value of the sounding built environment and the entire city. However, public space does not produce direct economic returns. In other words, public space produces social values which are difficult to be quantified or assessed. It, thereby, determines that urban space, as a resource, must be intervened by the government (as the manager of its public interests) through regulatory, public-private partnership, or direct operation / management to maximize its social value.

\section{What Changes Can "Sharing" Bring to the City?}

The spatiality, right and responsibility, and the social value of public space extend and complicate the understanding of urban space under the concept of sharing. As the medium and catalyst of urban process, urban space can improve users' spatial experience and influence on the social mechanism through optimal utilization, the division and transfer of the right to use, and decentralized organization.

\subsection{Optimal Utilization of Urban Space}

Urban space is a special type of resource; the public urban space is an especially rare resource belonging to the entire urban community, which can create enormous social values, and yet has the potential to be better utilized.

In sharing economy, the information tools and the transfer mechanism of right to use allow a large number of resources, which once could only be used by the stakeholders (often the owners), to be more frequently and better utilized by the people who once did not own the right to use. For an ordinary user, the possibility of temporarily occupying goods or resources that belong to other people enriches their options on the amount and types of available resources. The enhanced accessibility and flexible use mode allows once single functional space to be best utilized by different users that support the diversity and vitality of urban life.

\subsection{Decentralized Organization Structure - Encouraging Social Participation}

The sharing of urban space should be based on the process of implementation and supported by the diversity of participators. Sharing not only means an urban space is open to everyone, but also involves the rethinking of the mechanism supporting the space and introducing various participators and stakeholders into the process of the space forming.

Mobile Internet has substantially increased people's ability to access, interpret, and use information. Through various social media, sensors, and fast- 
changing information tools, human's behaviors and ideas can be digitized for real-time interaction. In this way, the connection between individuals and space can be digitized, and spread and superposed by the Internet that allows both present and absent individuals to be engaged with and contribute to the space forming.

\subsection{Transfer of the Right and}

Responsibility - the Essence of City Sharing

The essence of sharing economy is the division and transfer of the right to use. In terms of urban space, we focus on: in order to maximize the efficiency and generate more social values of urban space, what kind of rights and responsibilities shall we delimit and transfer?

1) The right to use: Instead of possession, diverse joint-uses are encouraged.

2) The right to construction and management: empowered by authorities, and introducing multi-stakeholders participation mechanism into the construction and management of the public space. On the one hand, private corporations and institutions are able to participate into the construction and management of urban infrastructure and public space through public-private partnership, to improve the supply efficiency and flexibility of public service. On the other hand, introducing public participation mechanism can increase the ways for citizens to participate into the construction of urban space. This will help eliminate the separation between the management process and the use process, and facilitate diverse social participation and management of the city.

3) Co-ownership and community: space forming and construction facilitates the users and community members to take the responsibility, changing their roles from participants to stakeholders. Through Internet networks the sharing economy can help establish online communities with common interests, space-based organizations and network platforms can also be formed, including community management organizations, foundations, and other autonomous organizations which would eventually become an influential power to the urban space forming and management.

As Duncan McLaren and Julian Agyeman concluded in their book Sharing Cities, the "sharing paradigm" can cover multiple dimensions including sharing goods, sharing services, and sharing activities or experiences. It also includes sharing between private individuals and public resources provided collectively or by the state.
When a city can break the monopolistic, exclusive process, "the creative energy of large numbers of citizens is coordinated, usually through a digital platform, outside of the parameters of the traditional hierarchical and mercantile organization resulting in the public provision of common resources." These communal approaches are also called "the collaborative commons" or "commons-based peer production., ${ }^{, 4]}$

\section{What Obstacles Are Urban Space Sharing Facing?}

Urban space is a huge continuum. The sharing of urban space, comparing with ordinary goods, confronts more difficulties and problems in both the overall and local levels. Space, as an organic whole, yet lacks a leading factor of integrating all the parts of urban management. A spatial forming process is often determined by different authorities including parks and recreation, transportation, urban management, etc. The unity of the space process and the fragmentation of spatial management has resulted in governance vacuum and lack of high quality space supply.

This lack of high-quality "spatial products" leaves much of market shares of providing urban public services (which ought to be provided by the 
government) to private suppliers that results in a lot of pseudo-public space ${ }^{[5]}$ : public business streets are replaced by shopping centers, urban residential areas are replaced by gated communities, and public parks are replaced by ticketed theme parks. The number of green space, courtyards, and small squares is increasing, which can only be used by a few citizens. Regardless of their openness or accessibility, technically they are no longer public spaces. They are, instead, private territories whose owners or managers have the right to make certain regulations for security and management that will limit the accessibility and reduce the authenticity of the site. ${ }^{[6]}$

The concept of privately-owned public space has been widely adopted by cities around the world after several worldwide and regional economic crises. ${ }^{[7]}$ In New York, for example, over 500 private public spaces had been created, according to the non-profit organization Advocates for Privately Owned Private Space ${ }^{(1)}$ since the instruction of the concept of incentive zoning by the 1961 Zoning Resolution which encouraged developers of office buildings and apartment towers to incorporate public plazas into their projects. As to London, according to a survey by The Guardian, the privatelyowned urban space first emerged in the 1980 s, and there has been a stable growth since $2000^{2}$.

This growth conforms to the extensive privatization process of governance and management in postmodern cities that is fundamentally driven by the transformation of the social-economic structure and the strategic withdraw of governmental functions under the neo-liberal framework: the government narrows their scope of public administration, reduces the investment in public space, and transfers the operation right of a significant portion of public resources to private capital operations. This is not about the expansion of public authority; on the contrary, it is the absence of public authority in urban space that makes an open and shared future of urban space meaning a lot.

\section{An Alternative: Exploring in the Revolution of Sharing}

An open and shared future of urban space is not only an imagination. It can be reached through the solutions responding to the common challenges that the cities are currently facing and the new opportunity brought by new technologies and public awakening.

In the city of San Francisco, where sharing economy grows rapidly, the Mayor's Office of Civic Innovation launched a project called "Living

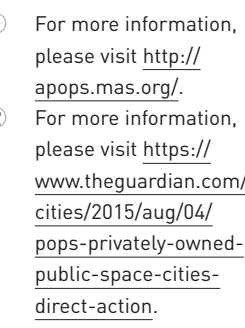


3) For more information, please visit http://www. sfliz.com/

4) For more information, please visit https:// www.nycgovparks.org/ planning-and-building/ without-borders.

without-borders.

For more information please visit http:// english.sharehub.kr/ infographic-sharingcity-seoul-4-yearsachievements/.

6) For more information please visit http:// news.xinhuanet.com/ politics/2015-06/25/ polics/2015-06/25/

c_127950035.htm.

For more information, please visit http://2015 susas.com.cn/cn/abou For more information, please visit http://www. dashilar.org/.

9) For more information, please visit http://www btsremade.org/zh/.
Innovation Zone" (LIZ) - a special area on the main streets designated for encouraging and supporting citizens, artists, and urban workers to test their ideas, projects, and technologies about space. Since 2013, LIZ has supported and built six projects through an open call process, becoming a real laboratory of public space ${ }^{3}$. In New York, a city park promotion project called "Parks without Borders" has been implemented since 2015. With a total budget of more than 50 million dollars, the project focused on the corners, borders and other areas that are not fully utilized in parks in the city. By removing the park fences and landscape improvement, the accessibility and attractiveness of the public space has been greatly improved. ${ }^{(4)}$

Seoul has launched the Sharing City Seoul Initiative Since 2012. The city has implemented a number of sharing initiatives covering vehicle, publication, public resource, and housing. The citizens also get accessibility to public facilities: public buildings and other resources are open for public use in nonworking hours. Up to 2016, a total of more than 1,200 public spaces were used by over 310,000 person-time ${ }^{(5)}$

In Shenzhen, 68 street artists were certified as the first batches of street artist in 2015, since when public art events were incorporated into urban administration. ${ }^{(6)}$ In Shanghai, the Urban
Space Art Season, since 2015, brings city administrators, users, planners, artists, and enterprises together to explore and improve urban public space. ${ }^{(7)}$ In Beijing, many micro-renewal initiatives, represented by "Dashilar Project" (8) and "Baitasi Remade Project," (9) became the precedents in the practice of urban space management.

The urban revolution from monopoly to openness, from possession to co-ownership, and from community to commune offers valuable experience of city forming and creation to envisioning a bright future of the cities. These practices, at the same time, reveal some key issues concerning urban management and public space:

1) Fragmentation of spatial management: the administration and management right of urban public space is divided into different authorities according to the resource types that results in that physical resources are overemphasized while the spatial process often being ignored, causing the lack of main body or overlapping problems in space management.

2) Incentive mechanisms for social participation: the positive effect of high quality public spaces on cities and sites is long-term and can be hardly quantified. It is foreseeable that if this externality can promote / drive urban management and multi-stakeholder participation, the engagement of the cities and individuals to urban space will be significantly increased.

3) The lack of spatial credit system: a sound credit system is necessary to sharing economy. The process of paying, evaluation, and feedback helps establish a well-organized sharing framework and enhance the overall security of the credit system. In the current process of urban spatial forming, one of the unresolved problems is how to establish trust and cooperation mechanism between different social communities and classes to introduce new participants to share the rights and responsibilities. LAF

REFERENCES

[1] Hamari, J., Sjöklint, M., \& Ukkonen, A. (2016). The Sharing Economy: Why People Participate in Collaborative Consumption. Journal of the Association for Information Science and Technology, 67(9), 2047-2059. doi:10.1002/ asi.23552.

[2] Lefebvre, H. (1991). D. Nicholson-Smith (Trans). The Production of Space. Oxford: Blackwell.

[3] Bao, Y. M. (2003). Modernity and the Production of Space. Shanghai: Shanghai Education Publishing House.

[4] McLaren, D., \& Agyeman, J. (2015). Sharing Cities - A Case for Truly Smart and Sustainable Cities. Cambridge: The MIT

[5] Sorkin, M. (1992). Variations on a Theme Park: The New American City and the End of Public Space. New York: Hill and Wang.

[6] Xu, M., \& Yang, Z. (2010). Genesis and Essence of Gated Community: From the Perspective of Spatial Political Economy. Urban Planning Forum, 23(4), 36-41.

[7] Goldberger, P. (1996). The Rise of the Private City. In V. Julia (Ed.), Breaking Away: The Future of Cities - Essays in Memory of Robert F. Wagner, Jr. New York: Twentieth Century Fund. 